\title{
Standardization of the Reaction Temperature for the Determination of Enzyme Activity
}

\author{
By H. U. BergmeYer
}

Department of Biocbemistry, University of Wuerzburg and Biochemica Werk Tutzing, Boebringer Mannbeim GmbH

(Eingegangen am 20. Oktober 1972)

\begin{abstract}
In view of the world-wide efforts to optimize and standardize the determinations of enzyme activities in clinical chemistry, the agreement upon a uniform reaction temperature is of essential importance. Both on the basis of practical technical considerations and for physical chemical reasons, $25^{\circ} \mathrm{C}$ is the best temperature for standard measurements.

The following considerations make the lowest possible temperature desirable: a minimal difference between room temperature and the measurement temperature reduces temperature variations in the cuvette, and allows measurements to be made near the temperature of calibration of pipettes and other volumetric vessels. Substrates are often not soluble enough to allow optimal concentrations for reactions at higher temperatures. The inactivation of proteins under measurement conditions distinctly increases with temperature. Problems with allosteric enzymes also make a low temperature desirable.

The understandable desire for the greatest possible measured effect in the shortest time (that is, high reaction rates) presses for the highest possible reaction temperature. This dilemma makes $25^{\circ} \mathrm{C}$ appear an optimal measurement temperature, especially since the $37^{\circ} \mathrm{C}$ which is often chosen for emotional reasons no more corresponds to "physiological" conditions than the other parameters in the cuvette.

Attempts are made repeatedly to find correlations between values measured at different temperatures by the use of correction factors, especially when automatic analyzers are used. Reasons for caution with respect to this practice arc given, and the consequences for the further development of clinical chemistry are discussed.
\end{abstract}

Angesichts der weltweiten Bemühungen um Optimierung und Standardisierung der Enzymaktivitätsbestimmungen in der klinischen Chemie ist die Festlegung einer einheitlichen Reaktionstemperatur von grundlegender Bedeutung. Sowohl technisch praktische wie physikalisch chemische Gründe sprechen für $25^{\circ} \mathrm{C}$ als Meßtemperatur.

Die geringere Differenz zur Raumtemperatur (geringere Temperaturschwankungen in der Küvette, Annäherung an die Eichtemperatur von Pipetten und anderen Meßgefäßen), die oft ungenügende Löslichkeit von Substraten (nicht mehr genügend für optimale Konzentration bei erhöhter Temperatur), die mit der Temperatur deutlich zunehmende Inaktivierung von Enzymproteinen unter Meßbedingungen und die Probleme mit allosterischen Enzymen verlangen eine möglichst niedrige Temperatur bei der Messung. Der verständliche Wunsch nach einem möglichst großen Meßeffekt in kurzer Zeit (d. h. hoher Reaktionsgeschwindigkeit) verlangt nach einer möglichst hohen Reaktionstemperatur. Dieser Zwiespalt läßt $25^{\circ} \mathrm{C}$ als eine optimale Meßtemperatur erscheinen, zumal die oft aus emotionalen Gründen gewählten $37^{\circ} \mathrm{C}$ ebensowenig den ,physiologischen“ Bedingungen entsprechen wie die übrigen Parameter in der Küvette. Besonders bei der Verwendung von Analysenautomaten wird immer wieder versucht, durch Umrechnungsfaktoren den Anschluß an Meßwerte bei anderer Temperatur zu finden. Die hierbei gebotene Vorsicht wird ebenso begründet wie die Konsequenzen für die weitere Entwicklung der klinischen Chemie aufgezeigt werden.

The temperature of measurement plays a decisive role in the determination of enzyme activity. Not only the velocity of the reaction, but also the optimum concentration of all reactants, such as substrates and coenzymes, as well as the $\mathrm{H}^{+}$concentration and, therefore, the $\mathrm{pH}$-value, are temperature dependent. Agreement on a standard temperature has to precede all standardization efforts of assay methods.

The setting of a measurement temperature based on emotional, traditional or formal view-points would be detrimental to the practice of clinical chemistry. As for any other analytical method the most important criterion is the quality of the result, its correctness and its precision (1). The standard temperature can be based only on experimentally proven facts.

According to the opinion of the Expert Panel on Enzymes of the International Federation of Clinical Chemists and of the Associated Members from different nations, $25^{\circ} \mathrm{C}$, $30^{\circ} \mathrm{C}$ and $37^{\circ} \mathrm{C}$ may be discussed as temperatures of measurement. Agreement was obtained (2) that the errors of a method caused by changes in temperature should not exceed $\pm 0.5 \%$. Therefore, the temperature of measurement must not vary more than $\pm 0.05^{\circ} \mathrm{C}$. The following alternatives have to be decided upon before starting the discussion on the actual standard temperature:

Definition of a single standard temperature, applied all over the world, for all methods and all enzymes, - Definition of a standard temperature for each individual enzyme,

- Definition of an individual standard temperature for each of the various methods of activity measurements for each enzyme.

Since optimized methods are only optimal insofar as they are practicable, all parameters dependent on temperature of measurement must be within practical limits. Thus, to define a standard temperature for the measurement of enzyme activities, two basic aspects have to be considered: 
- The technical aspects, including maintenance of a correct and constant temperature, calibration of the apparatus, solubility and stability of the reagents,

$\downarrow$ the physico-chemical properties of enzyme proteins at various temperatures.

\section{Technical Aspects}

\section{Accuracy and control of the reaction} temperature

A correct temperature is obtained by referring to the International Practical Temperature Scale (3). Fluctuations from the baseline have to be watched carefully (4). BowERs (2) demonstrated that even the top quality thermometers which are commercially available require corrections (deviations up to $0.29^{\circ} \mathrm{C}$ ).

For the control of the correct reaction temperature, measurements were performed in a jacketed cuvette (2). The results are shown in Table 1.

Tab. 1

Control of the reaction temperature (acc. to BowERS) Values in ${ }^{\circ} \mathrm{C}$

\begin{tabular}{cccc}
\hline $\begin{array}{c}\text { Actual cuvette } \\
\text { temperature } \\
\text { achieved }\end{array}$ & $\begin{array}{c}\vdots \text { iRoom } \\
\text { temperature }\end{array}$ & $\begin{array}{c}\text { Cuvette } \\
\text { jacket }\end{array}$ & $\begin{array}{c}\text { Water } \\
\text { bath }\end{array}$ \\
\hline 25.0 & 25 & 25 & 25.0 \\
& 27 & - & 24.7 \\
30.0 & 32 & 29 & 24.0 \\
37.0 & 27 & 31 & 30.0 \\
& 32 & 31 & 29.8 \\
& 27 & 33 & 37.5 \\
\hline
\end{tabular}

The temperature of measurement within the cuvette becomes less stable and accurate when the difference between room temperature and the required temperature in the cuvette increases. Figure 1 (2) demonstrates the difficulty of maintaining an accurate cuvette temperaturewhen it differs greatly from room temperature. First, it shows that at constant room temperature, the water bath must be set at a higher temperature in order to obtain a high cuvette temperature, and conversely, lower for a low cuvette temperature. It also shows how much heat flow from or to the cuvette occurs when the lid is opened for one or two minutes (arrows). These effects are least at $25^{\circ} \mathrm{C}$.

If a separate "optimum" temperature is set for every enzyme or every method, one might have to adjust the thermostat to another temperature before assaying the activity of another enzyme. One cannot over-emphasize the potential sources of error resulting from such a situation. For this reason, one single standard temperature should be defined for all methods and all enzymes.

Considerable changes in temperature are caused by necessary manipulations within the cuvette, such as the addition and mixing of small volumes of the test components. Most recent investigations (2) (Fig. 2) demonstrate the slow rate of temperature equilibration within aqueous solutions. Even such a small volume as $0.3 \mathrm{ml}$
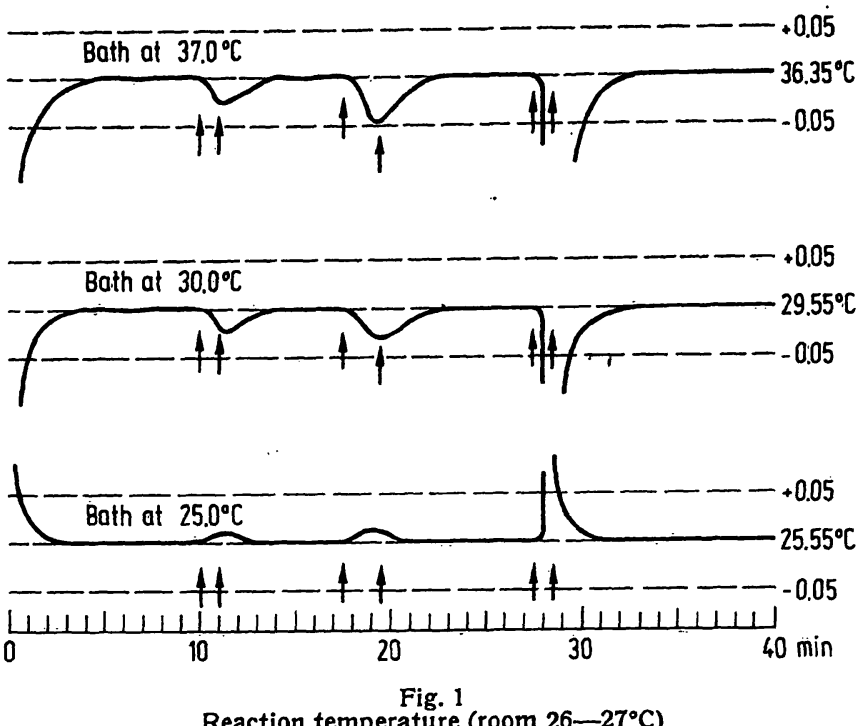

Reaction temperature (room $26-27^{\circ} \mathrm{C}$ )

Temperature changes during and after opening of cuvette lid for one or two minutes (between arrows) if bath temperature. of $37.0,30.0$ or $25.0^{\circ} \mathrm{C}$ is maintained. The ordinate of the three diagrams gives the actual measured temperature within the cuvette

$$
\text { at } 35^{\circ} \mathrm{C}
$$

reset to $25^{\circ} \mathrm{C}$

at $35^{\circ} \mathrm{C}$

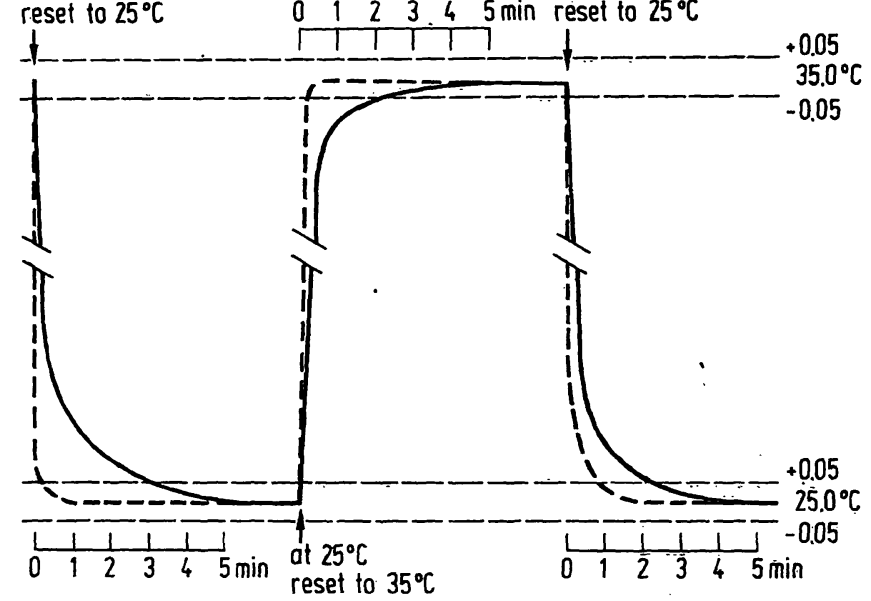

Fig. 2

Temperature response of reaction mixture

Difference in temperature adjustment during changes of temperature in the range of $10^{\circ} \mathrm{C}$ between metal block (broken line) and $0.3 \mathrm{mI}$ water reaction mixture (solid line) contained therein

requires $3-4 \mathrm{~min}$. more for equilibration than does the metal block surrounding the cuvette.

The simplest solution would be to keep the whole laboratory at the same temperature as that used for the enzyme activity measurements. However, this is not realistic for elevated temperatures, such as $37^{\circ} \mathrm{C}$. For the reasons above, a measurement temperature should be chosen which is as close as possible to the average room temperature of industrialized countries. This temperature is within the range $20^{\circ} \mathrm{C}-30^{\circ} \mathrm{C}$.

\section{Apparatus}

The equipment for temperature adjustment of the cuvettes must have a sufficient heat capacity to compensate for the external temperature changes.

When water-thermostats are used, the water has to flow with sufficient velocity through the system to ensure rapid equilibration. The equipment for cooling required for measurements at lower reaction temperatures does not represent a technical problem to-date. Equipment 
used for temperature measurement within the cuvette should have a low heat capacity in order to avoid influencing the true reaction temperature. On the other hand, the result should not be obtained too slowly.

Photometry is the most widely used principle of measurement in clinical chemistry, and absorbancy curves are more or less dependent upon temperature. For example, the absorption maximum (5) of $p$-nitrophenol, a reaction product of the alkaline phosphatase (EC 3.1.3.1) action $(\mathrm{pH}=10.17)$, lies between $402 \mathrm{~nm}\left(20^{\circ} \mathrm{C}\right)$ and $408 \mathrm{~nm}$ $\left(40^{\circ} \mathrm{C}\right)$. Although it is preferable to measure at the peak of the absorbancy curve, one frequently has to choose a wavelength on the slope of this band. In such cases even small temperature-dependent shifts of the absorbtion curves cause relatively large errors. For example, the extinction for $\mathrm{NADH}$ at $365 \mathrm{~nm}$ decreases by $1 \%$ for every $10^{\circ} \mathrm{C}$ rise in temperature (6). In every case, this dependence on temperature has to be considered and new determinations for $\varepsilon$ are required when measurements are to be performed at higher temperatures. Temperature dependence of fluorescence also has to be considered. The fluorescence of $\mathrm{NADH}$, for instance, decreases by about $7 \%$ with rising temperature from $25^{\circ} \mathrm{C}$ to $37^{\circ} \mathrm{C}$ (see M. Rotr (6a)).

The $\mathrm{pH}$-value of buffer solutions also depends on temperature (Example: $0.1 \mathrm{~mol} / 1$ Tris buffer is $\mathrm{pH}=8.0$ at $25^{\circ} \mathrm{C}$, but $\mathrm{pH} 7.68$ at $37^{\circ} \mathrm{C}$ !). The buffer compositions used for a defined $\mathrm{pH}$-value are tied to a defined temperature, usually $20^{\circ} \mathrm{C}$ or $25^{\circ} \mathrm{C}$. It is possible to calculate temperature conversion factors from the dissociation constants of the individual buffer substances. However, these are not valid (7) if the buffer solutions contain additional reactants which influence the dissociation of the buffer components or possess buffer capacities of. their own. To obtain correct $\mathrm{pH}$-values in reaction solutions, $\mathrm{pH}$-meters with glass electrodes have to be used, and these must be calibrated with calibration buffers standardized for the respective temperature.

Pipettes, volumetric flasks and volumetric cylinders are usually calibrated for $20^{\circ} \mathrm{C}$, rarely for $25^{\circ} \mathrm{C}$, and never for $37^{\circ} \mathrm{C}$. All volumetric equipment required has to be calibrated for the measurement temperature. The cubical expansion coefficient of glass is less than one tenth of the coefficient of water. Therefore, only the latter has to be considered. For the temperature difference of $20^{\circ} \mathrm{C}-37^{\circ} \mathrm{C}$, a volume error of $+0.5 \%$ exists. Calibration errors for temperatures between $20^{\circ} \mathrm{C}$ and $25^{\circ} \mathrm{C}$ are about $+0.15 \%$ and may be neglected.

\section{Solubility of the reagents}

It is often difficult to saturate enzymes with their substrates. For the enzyme catalase (EC 1.11.1.6), for instance, substrate saturation cannot be attained, since the substrate $\mathrm{H}_{2} \mathrm{O}_{2}$ in a high concentration destroys the enzyme.

Other enzymes are inhibited when the substrate concentration reaches values which fulfill the condition $[\mathrm{S}] \gg K_{m}$. This condition, which is derived from the
Michaelis-Menten equation for maximum velocity $(V)$ of the enzyme reaction, permits the calculation of the necessary substrate concentration. Frequently, however, the calculation furnishes a value which is unrealistic because such relatively high substrate concentrations inhibit the enzyme. The curve of dependence $V$ from the substrate concentration passes a maximum instead of approaching asymptotically the saturation value. In these cases, the optimum substrate concentration is a compromise and it is not identical with the saturation concentration.

It is often impossible to saturate the enzyme with substrate for reasons of solubility. Examples are $\gamma$-glutamyl transpeptidase (EC 2.3.2.1) with L- $\gamma$-glutamyl-p-nitranilide, and leucine arylamidase (EC 3.4.1.2) with L-leucine $p$-nitranilide.

For these clinically relevant enzymes, the substrate concentration which can be achieved for measurement at $25^{\circ} \mathrm{C}$ is almost optimal. However, to obtain optimum concentrations for $37^{\circ} \mathrm{C}$ would be rather difficult. It is known (see for example (8)), that the $K_{m}$-values of an enzyme become larger with increasing temperature. Consequently, it is necessary to use more substrate to attain optimal activities $(V)$. This can mean an order of magnitude for the temperature difference of $37^{\circ} \mathrm{C}$ to $25^{\circ} \mathrm{C}$ (e. g., lactate dehydrogenase (EC 1.1.1.27)(9)).

The solubility of the reagents may limit attempts to measure enzyme activity under optimum conditions. The higher the reaction temperature, the narrower the limits.

\section{Stability of reagents}

Since the addition of even small volumes to the equilibrated cuvette contents significantly changes the temperature of the reaction, the solutions of all participants in the reaction must be pre-equilibrated. In clinical chemistry laboratories, it is routine practice to keep the reagents at hand for at least $1 / 2$ day. This means that for measurements at increased temperatures (e. g., $37^{\circ} \mathrm{C}$ ) solutions of necessary reactants have to be stable for at least 5 hours. The amount of deviation permitted from optimal concentrations (or activities of auxiliary and indicator enzymes) depends on the change of reaction rates caused by changes in these concentrations or activities. If a distinct maximum exists [as in the case of glutamate dehydrogenase (EC 1.4.1.2) activity, which depends upon NADH concentration (see 1. c. (10) for example)], or if for practical reasons the "optimum" concentration is not attained, a decrease of concentration of about $10 \%$ during storage at $37^{\circ} \mathrm{C}$ causes an unacceptable error in the result. In the case of other substrates, and for most of the indicator and auxiliary enzymes, major deviations of about $20 \%$ are still tolerable. The data in Table 2 (11) demonstrate that, for the creatine kinase (EC 2.7.3.2) assay, the concentration of the glutathione solution is critical. In general therefore, it appears that the task of keeping reagent solutions for enzyme assays at $37^{\circ} \mathrm{C}$ for several hours is incompatible with the requirement that accurate results be obtained with methods standardized at that temperature. 


\begin{tabular}{lcc}
\hline \multicolumn{1}{c}{ Reagent solution } & $\begin{array}{c}\text { Content as percentage of } \\
\text { initial values } \\
\text { after } 1 \times 5 \mathrm{~h}\end{array}$ & after $2 \times 5 \mathrm{~h}$ \\
\hline Glutathione (-SH) & $84 \%$ & $\mathbf{7 6 \%}$ \\
Creatine phosphate & $99 \%$ & $97 \%$ \\
NADP & $100 \%$ & $92 \%$ \\
Hexokinase (EC 2.7.1.1) & $85 \%$ & $\mathbf{7 9} \%$ \\
Glucose-6-phosphate dehydrogenase & & \\
$\quad$ (EC 1.1.1.49) & $86 \%$ & - \\
NADH & $97 \%$ & $\mathbf{7 5 \%}(3 \times 5 \mathrm{~h})$ \\
\hline
\end{tabular}

Tab. 2

Stability of some reagent solutions

(after one or two incubations for $5 \mathrm{~h}$ at $37^{\circ} \mathrm{C}$. Concentrations of the solutions used are those given (10) for the creatine kinase-test. Concentration of the NADH solutions as given for the lactate dehydrogenase-test)

\section{Summary of the technical aspects}

Reagents for measurement of enzyme activities are most stable at low temperatures. Their storage in the refrigerator has been proven successfully. Also, growth of microorganisms is reduced. Thus, each increase in temperature is a concession.

The measurement temperature can be more precisely maintained, the smaller the temperature difference between the cuvette'and its surroundings. This favours $25^{\circ} \mathrm{C}$ as measurement temperature. Also, at this temperature fewer difficulties arise with the calibration of pipettes, volumetric flasks, buffers, and determination of coefficients of absorbancy.

The solubility of some substrates is only sufficient to obtain optimal concentrations in the assay mixture for $25^{\circ} \mathrm{C}$. This is no longer practicable for $37^{\circ} \mathrm{C}$ in some important cases.

\section{Physical-chemical Properties of Enzyme Proteins at Various Temperatures}

It is understandable that for routine measurements in clinical chemistry one wants to obtain the largest possible readings, or to use the smallest possible sample volumes, and still obtain the same given readings. The simplest way to obtain this is by an increased reaction temperature $(1,12)$. It should not be forgotten, however, that there are also other possibilities; e. g. doubling the light path of the cuvettes or the use of more sensitive measuring techniques, for example fluorimetry. The use of higher temperature assumes a relatively long period of time for equilibration of the assay mixture, besides equilibrating the reagent solutions (see above). However, all experience in preparative enzymology contraindicates the use of heat on diluted enzyme solutions.

During the isolation of enzymes from biological material one works in the cold, otherwise proteases in the starting material would rapidly destroy enzymes or heavy metals would inactivate them. Samples of serum are comparable to such crude enzyme solutions. It is obvious to a biochemist that he must protect diluted enzyme solutions against inactivation by addition of protective colloids (e. g. albumin), chelating agents (e. g., EDTA) and cooling to about $+4^{\circ} \mathrm{C}$. This has been successfully done in practice. In spite of this, some clinical chemists want to incubate and measure at $37^{\circ} \mathrm{C}$.

Both possibilities (the lowest possible and the highest possible temperature) have to be examined with regard to their practical aspects.

\section{Measurements under "physiological"}

$37^{\circ} \mathrm{C}$ cannot be called the physiological temperature, as this, of course, refers to the temperature of the periphery of adult man.

The organs whose cells release those enzymes found in the serum under pathological conditions may have temperatures which are significantly different from $37^{\circ} \mathrm{C}$. If one were to measure enzyme activities at $37^{\circ} \mathrm{C}$, only one of many parameters would have been adjusted to physiological conditions. Almost all other conditions differ in vivo from those in vitro. One measures the maximum possible action of the enzyme under optimal conditions, while in the cells, the reaction generally proceeds with half maximum velocity at the most. The concentration of the enzyme to be measured in the assay mixture is much lower than under physiological conditions. It is known that the entire cytoplasm of the cell consists of dissolved enzymes. HEss (13) showed that conditions similar to the physiological state can be realized in the cuvette only with enzyme concentrations of $0.2 \mathrm{mmol} / 1$ to $2 \mathrm{mmol} / 1$. In practice this is hard to realise due to the high viscosity of such concentrated protein solutions.

We have to accept that measurements of enzyme activity in vitro cannot be performed under physiological conditions for practical reasons. Since we want to stick to the definition of enzyme activity as maximum enzyme action, we cannot measure under physiological conditions. The necessity of measuring with highly diluted enzyme solutions requires the best possible protection of the enzyme protein in solution. It is generally agreed that one does not want to measure the activity of artifacts, but of native enzymes.

\section{Heat effects on enzyme proteins}

The effect of heat on dissolved proteins has been investigated for a long time (see e. g. (14)). In the long run, elevation of temperature causes both heat aggregation and heat denaturation (15). In enzymology and clinical chemistry the terms "denaturation" and "enzyme-in= activation" are often used interchangeably (12): They must be strictly separated. In order to inactivate the protein molecules much smaller changes in conformation are necessary than for their denaturation (16). Even the small structural changes necessary for the inactivation may easily be detected, e. g. by measurement of optical rotatory dispersion $(14,17,18)$. Although various parameters of thermal denaturation have been measured in several enzymes of interest in clinical chemistry (cf. e. g. 16, 19, 20), there is an obvious lack of thorough 
systematic investigations of heat inactivation of serum enzymes under commonly used conditions of measurement.

It has been shown (21) that protein molecules unfold at elevated temperature. Thus, peptide bonds protected in the native protein (at low temperature) become open to attack by proteases. This, however, explains only the findings from preparative enzymology. The dependence of protein concentrations, temperature and the parameters of the solvent, as well as the dependence of the heat effect upon the number of SH- und SS-bonds in the protein molecules, upon its net charge and its secondary and tertiary structure, are extremely complex. Thus, one cannot make general statements on heat-inactivation, but must rely on individual results.

The isoenzymes of lactate dehydrogenase (LDH) appear to have been investigated best of all. In 1960 WRóbLEwSKr's group (22) reported on the heat inactivation of rabbit lactate dehydrogenase (LDH)-isoenzymes and on the temperature dependence of their concentration optima for pyruvate. Vesell (23) obtained similar results. Rat $\mathrm{LDH}-5$ is considerably less stable at $39^{\circ} \mathrm{C}$ than $\mathrm{LDH}-1$. The rate of activity decrease depends on the enzyme concentration. LDH-5 is also more sensitive to proteases (24). Thus, the activity of enzymes in such a low concentration as occurs in normal serum, may drop within one hour at $39^{\circ} \mathrm{C}$ to less than $10 \%$ of the original activity. Even the time interval of 5-10 min. necessary for temperature adjustment causes an inactivation of about $10 \%$ for LDH-5 protein. Also, KAHN and SuEDI (25) found a definite concentration dependence of heat inactivation for lactate dehydrogenase pig muscle enzyme. The heart enzyme is more stable in every respect.

However, these groups exposed the enzymes to elevated temperature without addition of protective protein. Parallels for practical work with serum or plasma cannot be drawn without hesitation. Not without reason was it recently recommended to dilute highly active serum with inactivated serum for measurement and to use a fixed ratio of serum volume:test volume in standardized methods. Rabbit muscle LDH- 5 in $6 \%$ albumin solution shows no loss of activity after six hours at $37^{\circ} \mathrm{C}$, even in such a low concentration as $0.5 \mu \mathrm{g} / \mathrm{ml}$, quite in contrast to the unprotected solution (26).

KING (27) demonstrated that for serum aldolase, inactivation of the enzyme at $36.5^{\circ} \mathrm{C}$ increases with time (incubation times between 15 and $120 \mathrm{~min}$.).

Bowers and MCСомв (5) observed a 50\% loss of alkaline phosphate activity in serum at $37^{\circ} \mathrm{C}$ after one hour at $\mathrm{pH}=10.2$. This equals $10 \% / 10 \mathrm{~min}$. At optimum $\mathrm{pH}$ at this temperature ( $\mathrm{pH} 9.9$ ) a $28 \%$ loss of activity was observed $(2.8 \% / 10 \mathrm{~min})$, while at the $\mathrm{pH}$ optimum at $25^{\circ} \mathrm{C}$ and $30^{\circ} \mathrm{C}$ no inactivation occurs.

A prerequisite for stability investigations is the use of serum, plasma or solutions of similar protein concentration for the measurements. In order to recognize reversible heat inactivations, activity determinations should be performed at the same temperature as that used for the heat treatment.
Investigations on the long-term stability of enzymes in serum or plasma (cf. e. g. (7), (28)) may only give hints for a fixed internationally valid temperature. Decisive for this, however, are measurements of stability for short times during the assay and during the preceding period of temperature adjustment.

During measurement the enzyme (depending on the test) is present in a dilution of $1: 3$ to $1: 150$. However, it is protected by its substrate. In most cases measurement takes only a few minutes. However, in some cases critical measuring times of several hours occur (in the case of some peptidases).

Depending upon the equipment for thermal adjustment, periods of 5 to $15 \mathrm{~min}$ are used. It depends upon the assay methods whether the reaction is started a) with temperature-adjusted serum or b) with (one of) the substrate(s) or with the coenzyme. Assuming that only thermallyadjusted solutions or samples are pipetted, in case a) the enzyme has to be stable for about $15 \mathrm{~min}$ in the sample (possibly diluted with inactivated serum). In case b) the enzyme has to be stable in a dilution of up to $1: 150$ in the assay mixture without presence of substrate or coenzyme for at least $15 \mathrm{~min}$.

Such investigations are presently performed in the temperature range from $15^{\circ} \mathrm{C}$ to $40^{\circ} \mathrm{C}$ under individually optimized conditions (26). For example, significant loss in activity of creatine kinase can be seen for case a) as weil as for case $b$ ) during the temperature equilibration and measuring period $(26,29,30)$. Similar investigations check the validity of the ARRHENIUS equation, also at increased temperatures with the same measurement conditions. Szasz $(31,32)$ has already performed such measurements for enzymes of clinical importance. They show that changes of activation energy, caused by conformational changes of the enzyme protein may occur within an interesting temperature range. This has also been demonstrated by HeLnireich and Cori (33) for glycogen phosphorylase (EC 2.4.1.1) saturated by substrate. Generally, this and other allosteric enzymes may change by complex mechanisms to different conformations, leading to different enzyme properties, just by preincubation at various temperatures.

\section{Summary to "Enzyme Proteins at Higher Temperatures"}

Enzyme proteins may be inactivated under measurement conditions at $37^{\circ} \mathrm{C}$. (The terms inactivation and denatutation are to be distinguished.)

$37^{\circ} \mathrm{C}$ as temperature of measurement by no means represents "physiological conditions". The advantages of greater sensivity during measurement at $37^{\circ} \mathrm{C}$ can be obtained by other means as well.

Allosteric enzymes may present properties at $37^{\circ} \mathrm{C}$ extremely different from those at $25^{\circ} \mathrm{C}$.

The stability of each enzyme protein is an individual property. As long as the stability of every enzyme of interest for clinical chemistry practice has not been measured comprehensively, for safety's sake a relatively low, 
and not a relatively high measurement temperature should be fixed internationally. Of course, investigations of stability at various temperatures and checking of the ARrHENIUS-plot require the determination of optimum values for all enzyme parameters for each of the applied temperatures.

\section{Temperature Problems with Automated Procedures}

\section{The various kinds of devices}

The practicability of methods for the determination of enzyme activities is of decisive importance for routine work in laboratories. The large number of analyses to be accomplished enforces the use of automatic analyzers of various constructions. There are two basic types: 1 . Those apparatus, which essentially mechanize the manual steps of the procedure (discrete analysers) and 2. those which employ procedures completely different from those done manually (continuous flow analysers). (Questions as to the definition of the term "automatic analyzer" will not be discussed in this paper.) For the latter type, it is difficult to define incubation and reaction temperatures or the exact period of time necessary for temperature adjustment; one refers to an enzyme standard. The first group of devices, which are more suitable for the measurement of enzyme activities, generally lack the equipment for temperature equilibration of the reagents; the reaction temperature is often pre-set as a fixed temperature; the ratio sample volume: test volume differs with different apparatus; the reactions are, unlike the manual techniques, mostly started with the substrate.

However, despite all the differences among the individual automatic devices the period of time for temperature adjustment is - very similar to that of manual methods - between $5 \mathrm{~min}$ and $20 \mathrm{~min}$. An exception are those apparatus with only $100 \mu \mathrm{l}$ test volume and $10 \mathrm{sec}$ for adjustment of temperature. Instead of the problem of temperature stability of sample and reagents, here the problem of temperature constancy must be encountered. Without evaluation of the qualities of the devices concerning sufficient time for temperature equilibrium, constancy of temperature during the reaction, etc., it can be stated that those problems regarding measurement temperatures which primarily occur when using manual methods, are in principle the same for the procedures with automatic analyzers. Since every automatic device represents a compromise in one way or another, one encounters rather larger problems regarding the temperature-dependent accuracy of the measurement compared with those in manual techniques.

In my opinion the main objections to the international agreement on a standard temperature come from the large laboratories. The use of very expensive automatic analyzers over a long period of time, some of which operate with an arbitrarily set temperature, complicates every change. Today even the possibility of a conversion of measured results by means of temperature correction factors (22) - which was already discussed in
1960 - is again occasionally proposed as an alternative to this situation.

\section{Conversion factors}

If such factors were established from a sufficiently large number of test persons, they would certainly be a valuable source of information for making these measurement results comparable to those obtained at different temperatures. If such factors are used as "correction factors", though, in order to convert the individual result to "standard conditions", then care has to be taken (34).

The fact that the optimal substrate concentration may increase between $25^{\circ} \mathrm{C}$ and $37^{\circ} \mathrm{C}$, in some cases by up to an order of magnitude (9), demands measurement at both temperatures under carefully determined optimum conditions. Still, the problem of the activity ratio of isoenzymes in the sample remains. This ratio varies in an unpredictible way for the various pathological states. Thus, only a kind of "standardization of average values" for the assay method is possible (7). Since the temperature dependence of various isoenzymes is different, even an exact knowledge of the temperature dependence will not help, due to the varying ratio of isoenzyme activities.

From this it may be derived, that temperature correction factors are permissible only within narrow limits (7). Since they yield only approximate values, they should be avoided. Measurement temperature and standard temperature should be identical (1).

\section{Summary to "Temperature Problems with Automatic Analyzers"}

Problems of the temperature of measurement are the same for procedures with automatic analyzers as they are for manual procedures. Generally they are larger rather than smaller.

Conversion factors understood as temperature correction factors should be avoided.

\section{Consequences}

If a fixed standard temperature for the measurement of enzyme activities in clinical chemistry is to be made "as optimum as possible, but practicable", the following conclusions may be drawn:

All practical considerations favour one uniform measurement temperature for all methods.

All scientific viewpoints oppose the use of correction factors for the conversion of results from one temperature to another.

It is true that the practical requirement for a greater sensitivity of assay methods favours a relatively high temperature, but this can be achieved by other means. All technical aspects favour a relatively low measurement temperature:

achievement of a correct temperature of measurement and its control, 
problem-free use of all measurement equipment for volumes, extinctions and $\mathrm{pH}$-values,

- limited solubility of some reagents,

limited stability of reagents.

All knowledge of physical-chemical behaviour of enzyme proteins favours a low temperature of measurement:

The experiences of preparative enzymology,

Measurement of heat inactivation of various enzymes.

For serum or enzyme solutions in $6 \%$ albumin only a few measurements are available, but they show that under optimal conditions for some enzymes, heat inactivation at $37^{\circ} \mathrm{C}$ may occur. Activity losses of, for example,
$2.8 \%$ during the period of temperature adjustment, as in the case of alkaline phosphatase are not tolerable (in contrast to (12)).

For good reasons, $25^{\circ} \mathrm{C}$ has been widely used as temperature of measurement since the beginning of routine measurements of enzyme activities in clinical chemistry. A change should not be made arbitrarily or because of traditional, emotional reasons, or because of convenience. Only new convincing measurement results would justify this.

As long as no agreement exists on the temperature of measurement, any further standardization of methods for enzyme activity measurements is impossible.

\section{References}

1. King, J. (1972), Ann. Clin. Biochem. in press. - 2. Bowers, G. N., Lecture 8th Int. Congr. Clin. Chem., Copenhagen 1972. 3. The International Practical Temperature Scale of 1968 (1969), Metrologia 5, 35. - 4. Swindells, J. F., Calibration of Liquid-in-Glass Thermometers. National Bureau of Standards Monograph 90, Superintendent of Documents, US Government Printing Office Washington, D.C. 20402. - 5. Bowers, G. N. \& McComb, R. B. (1966), Clin. Chem. 12, 70-89. - 6. Netheler, H. (1970), in Methoden der enzymatischen Analyse (BERGMEYER, H. U. ed.) 2nd ed., p. 153, Verlag Chemie, Weinheim. - 6a. Roth, M. (1969), in Methods of Biochemical Analysis (GLICK, D. ed.) vol. XVII, p. 189-285, Interscience Publishers, a Division of John Wiley and Sons, New York, London, Sidney, Toronto. - 7. Bergmeyer, H. U. (1972), Clin. Chem. 18, 1305-1311. - 8. Szasz, G., Round Table Discussion, loth Oct. 1972, 2ème Colloque, Automation et Biologie Prospective, Pont-à-Mousson, France. - 9. KING, J. (1967), Clin. Biochem. 1, $42-47$. - 10. Recommendations of the Dtsch. Ges. Klin. Chem. (1972) this j. 10, 281-291. - 11. Bernt, E. \& Bergmeyer, H. U., unpublished assays. - 12. Roth, M. (1972), Clin. Chem. 18, 739-740. - 13. Hess, B., Wreker, H. J. \& KrUEger, J. (1969), FEBS-Abstracts. - 14. BRANDTS, J. F. (1967), in Thermobiology (Rose, A. H. ed.), p. 25 to 72. - 15. JAENICKE, R. (1965), Wärmeaggregation und Wärmedenaturierung von Proteinen, DECHEMA-Monographien, vol. 56, p. 207-244, Verlag Chemie, Weinheim. - 16. Tanford, Ch. (1968), Adv. Protein Chem., vol. 23, p. 122-282, Academic Press, New York-London. - 17. Shellman, J. A. (1958), Compt. rend. trav. lab. Carlsberg Ser. chim. 30,415. - 18. Pollard, E. C.
(1964), Adv. Chem. Physics, vol. 7, p. 201-237 Academic Press, New York-London. - 19. URNes, P. \& Doty, P. (1961), Adv. Protein Chem., vol. 16, p. 401-544, Academic Press, New York-London. - 20. KadzmanN, W. (1959), Adv. Protein Chem., vol. 14, p.1-63, Academic Press, New York-London. - 21. Hermans, jr. J. (1965), in Methods of Biochemical Analysis (GLICK, D. ed.), vol. XIII, p. 81-111, Interscience Publishers, a Division of John Wiley and Sons, New York, London, Sydney. - 22. Plagemann, P. G. W., Gregory, K. F. \& WRóbLEWSKr, F. (1961), Biochem. Z. 334, 37-48. - 23. Vesell, E. S., Fritz, P. J. \& White, E. L. (1968), Biochim. Biophys. Acta 159, 236 - 243. 24. Vesell, E. S. \& Yielding, K. L. (1968), Ann. N. Y. Acad. Sci. 151, 678-689. - 25. Khan, M. G. \& Suedi, J. (1968), Acta Biochim. et Biophys. Acad. Sci. Hung. 3 (4), 409-420. - 26. Bernt, E. \& BergMEYER, H. U., unpublished. - 27. KING, J. (1965), Practical Clinical Enzymology, p. 32-33, van Nostrand, London. 28. Bergmeyer, H. U., Bernt, E., Grassl, M. \& Michal, G. (1970), in Methoden der enzymatischen Analyse (BERGMEYER, H. U. ed.) 2nd ed., p. 125-143, Verlag Chemie, Weinheim. - 29. Rosalki, S. B. (1967), J. Lab. Clin. Med. 69, 696-705. - 30. Mathieu, M. Round Table Discussion, loth Oct. 1972, 2ème Colloque, Automation et Biologie Prospective, Pont-àMousson, France. - 31. Szasz, G. (1969), Clin. Chem. 15, 124-136. - 32. Szasz, G. Lecture 8th Int. Congr. Clin. Chem. Copenhagen 1972, personal communication. - 33. HeLmReich, E. \& Corr, C. F. (1964), Proc. Nat. Acad. Sci. 52, 647-654. - 34. Gruber, W. \& Bergmeyer, H. U. (1971), Brit. Med. J., $749-750$.

Prof. Dr. H. U. Bergmeyer Boehringer Mannheim GmbH Biochemica Werk Tutzing 8132 Tutzing/Obb.

Bahnhofstr. 5 